\title{
INNOVATIVE CAPACITY OF UKRAINE'S ECONOMY IN THE INTERNATIONAL CONTEXT
}

\author{
Alla Rusnak' \\ Kherson Branch Admiral Makarov National University of Shipbuilding, Ukraine \\ Svitlana Prokhorchuk ${ }^{2}$ \\ Private Higher Educational Institution \\ "International University of Business and Law", Ukraine
}

\begin{abstract}
The purpose of the article consists in the determination of the level of innovation capacity of Ukraine in the international context based on the rating. The method of integrated research allows assessing the innovation of the country's economy and developing recommendations for its improvement. Methodology. The research is based on a systematic approach to determining the innovation capacity of the Ukrainian economy by international ratings that assess innovation potential, technological and innovation competitiveness. Determination of the innovation potential and innovation capacity of Ukraine's economy was carried out based on the Global Innovation Index, the Bloomberg Innovation Index, the Global Competitiveness Index, the Innovation Union Scoreboard, and the Global Talent Competitiveness Index. Innovation is a defining characteristic of modern scientific and technical, industrial, socioeconomic, and other social processes. Effective innovation potential is not only a way of dynamic development but also a means of ensuring the country's security and sovereignty, its competitiveness in the modern world. Results of the research indicate that the formation and implementation of innovation potential and the introduction of innovations in Ukraine is characterized by low indexes. Such preconditions for innovative development as human capital, education, and science receive relatively higher ratings (although there are problems in these areas that need to be addressed). Stable lower ratings (which stipulate the overall rating of the country) have political factors, the state of the regulatory environment and institutional preconditions for the transition to an innovative way of development. Practical implications. In order to increase the innovation capacity of the country's economy and within the framework of the European integration processes in the field of innovation policy of Ukraine, the following measures are proposed: to improve the framework conditions for innovation activity; to implement innovative partnerships; to strengthen tools to support innovations and simplify administrative procedures to facilitate access to financing, especially for small business entities; to stimulate the formation of partnerships and links between education, business, science, and innovation and to stimulate entrepreneurship by supporting young innovative companies. Proportion/originality. The results of the research made it possible to propose specific initiatives, the implementation of which will have a positive impact on the national innovation system and increase the innovative capacity of the Ukrainian economy, in particular: to accelerate the development and implementation of "innovation laws"; to review the list and content of the existing scientific and technical programs with the purpose of more consideration of the world tendencies and their adaptation to the needs of the national economy; to develop an innovation monitoring system, which would be based on the use of indexes of the European Innovation Scoreboard.
\end{abstract}

Key words: innovations, innovation potential, innovation development, competitiveness, institutions.

JEL Classification: O31, E02

\footnotetext{
Corresponding author:

${ }^{1}$ Department of Economics, Kherson Branch Admiral Makarov National University of Shipbuilding.

E-mail: rusnak_av@meta.ua

ORCID: http://orcid.org/0000-0002-3198-2866

${ }^{2}$ Department of Finance, Accounting and Taxation, Private Higher Educational Institution

"International University of Business and Law".

E-mail: lana_audit7@ukr.net

ORCID: http://orcid.org/0000-0003-1487-2291
} 


\section{Introduction}

Sustainable development of the Ukrainian economy is impossible without activating innovation activity. The country's innovation system allows us to combine economic and social relations, knowledge, and technological innovations. Innovation is a defining characteristic of modern scientific and technical, industrial, socioeconomic, and other social processes. Effective innovation potential is not only a way of dynamic development but also a means of ensuring the country's security and sovereignty, its competitiveness in the modern world.

The novelty of the research consists in improving the directions of raising the innovative capacity of the country's economy, in particular, within the framework of the European integration processes in the field of innovation policy of Ukraine.

The purpose of the paper consists in the determination of the level of innovation capacity of Ukraine in the international context based on the rating. The research is based on a systematic approach to determining the innovative capacity of the Ukrainian economy according to the international ratings that assess innovation potential, technological and innovation competitiveness. The main task is to determine the innovative potential and innovative capacity of the Ukrainian economy based on the Global Innovation Index, the Bloomberg Index of Innovation Development, the Global Competitiveness Index, and the Innovation Union Scoreboard, the Global Talent Competitiveness Index, and the development of proposals for improving the country's innovative potential.

\section{Ukraine's rating by the Global Innovation Index}

According to the Global Innovation Index 2017 Report prepared jointly by Cornell University, INSEAD the Business School for the World, and the World Intellectual Property Organization, the Global Innovation Index in 2017 covers 127 world economies and uses 82 indicators in a number of areas.

In 2017, Switzerland and Sweden have leading positions in the ranking as in 2016. The Netherlands take the third position, having improved their index by six positions. Also, the ten most innovative countries include: the USA, Great Britain, Denmark, Singapore, Finland, Germany, and Ireland (Dutta, Lanvin, WunschVincent, 2017).

In 2017, Ukraine occupied the highest position in the last 7 years $-50^{\text {th }}$ place (Table 1 ).

And in the group with an income below the average, Ukraine took $2^{\text {nd }}$ place after Vietnam, outranking Mongolia, Moldova, Armenia, and India. Compared to 2016, Ukraine has risen by 6 points, which is due to a high coefficient of innovative efficiency, that is, the ratio of the obtained result to innovative resources (6).
Table 1

The ranking of countries of the world in terms of innovative potential and indicators of economic competitiveness in 2016-2017

\begin{tabular}{|l|c|c|c|c|}
\hline \multirow{2}{*}{\multicolumn{1}{c|}{ Countries }} & \multicolumn{2}{c|}{$\begin{array}{c}\text { The Global } \\
\text { Innovation Index }\end{array}$} & \multicolumn{2}{c|}{$\begin{array}{c}\text { The Global } \\
\text { Competitiveness } \\
\text { Index }\end{array}$} \\
\cline { 2 - 5 } & 2016 & 2017 & 2016 & 2017 \\
\hline Switzerland & 1 & 1 & 1 & 1 \\
\hline Sweden & 2 & 2 & 6 & 7 \\
\hline Great Britain & 3 & 5 & 7 & 8 \\
\hline USA & 4 & 4 & 3 & 2 \\
\hline The Netherlands & 9 & 3 & 4 & 4 \\
\hline Germany & 10 & 9 & 5 & 5 \\
\hline China & 25 & 22 & 28 & 27 \\
\hline Poland & 39 & 38 & 36 & 39 \\
\hline Russian Federation & 43 & 45 & 43 & 38 \\
\hline Ukraine & 56 & 50 & 85 & 81 \\
\hline Kazakhstan & 75 & 78 & 53 & 57 \\
\hline
\end{tabular}

The basis of Ukrainian innovation competitiveness is human capital. Its effective implementation is the main competitive advantage. Compared to 2016, this indicator has decreased due to the reduction of government expenditures for education $\left(18^{\text {th }}\right.$ place in $2016,22^{\text {nd }}$ place in 2017) and science. In 2017, in the sub-index "Human Capital” Ukraine takes $41^{\text {st }}$ position versus $40^{\text {th }}$ in 2016 (Fig. 1).

A factor inhibiting innovative development is the low level of R\&D expenditures ( $54^{\text {th }}$ place in 2017), which causes the search for other sources of financing and the migration of scientists beyond the boundaries of Ukraine.

In 2017, Ukraine occupies the $101^{\text {st }}$ place by the sub-index "Institutions", as in 2016, including by the indicators as follows: political situation $-122^{\text {nd }}$ place $\left(123^{\text {rd }}\right.$ place in 2016), regulatory environment $82\left(84^{\text {th }}\right.$ place in 2016), situation of business environment $-78\left(79^{\text {th }}\right.$ place in 2016$)$.

In terms of infrastructure development, Ukraine takes $90^{\text {th }}$ place in the ranking against $99^{\text {th }}$ in 2016 . The market indexes of Ukraine are estimated at 43,2 points, which corresponds to the 81 st position (by loans $-71^{\text {st }}$, by the level of trade and competition $48^{\text {th }}$, by investments $\left.-107^{\text {th }}\right)$. By the "Business experience" sub-index, Ukraine rose to $22^{\text {nd }}$ position and took $51^{\text {st }}$ place (by the number of mental workers $41^{\text {st }}$ place, by innovation links $-72^{\text {nd }}$, by the perception of knowledge $-63^{\text {rd }}$ ).

According to the results of scientific researches, Ukraine is on $32^{\text {nd }}$ position in the ranking in 2017 against $33^{\text {rd }}$ in 2016, including by the indicators of knowledge creation - 16th place, by the influence of knowledge $-77^{\text {th }}$, by the distribution of knowledge $54^{\text {th }}$. By the sub-index "Creativity" the country has improved its position, moving from $58^{\text {th }}$ places to $49^{\text {th }}$, 


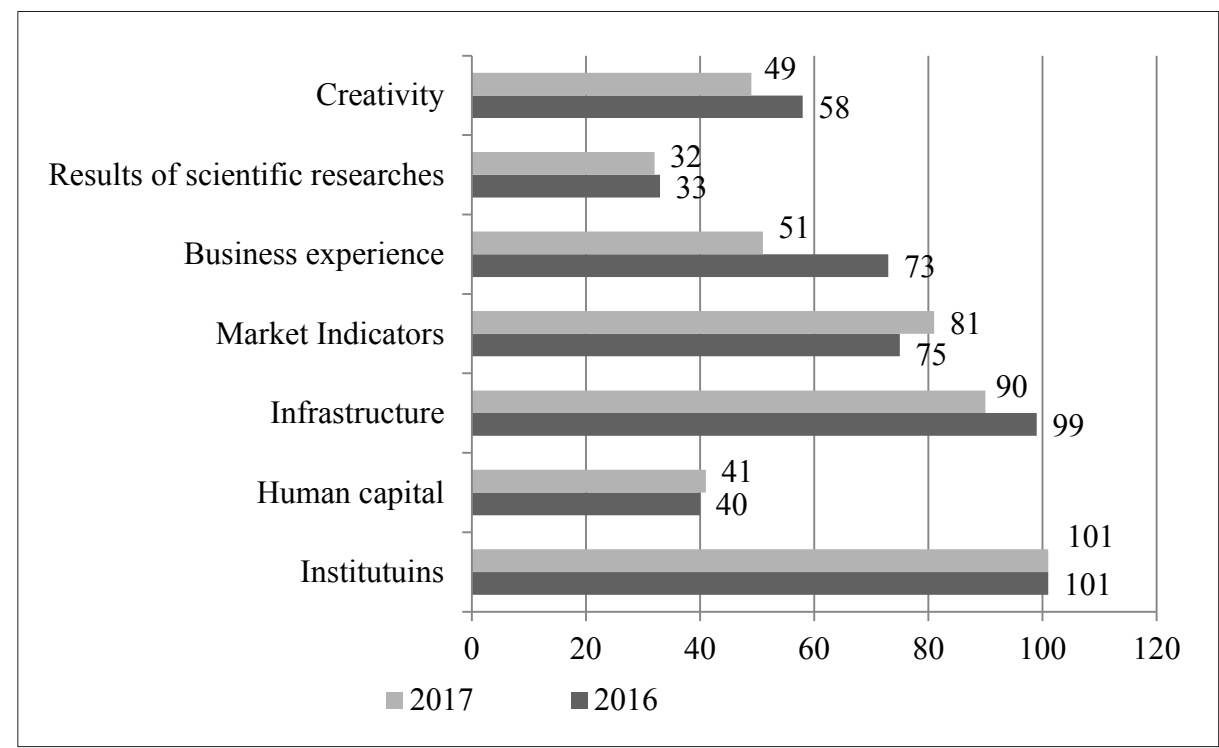

Figure 1. Dynamics of the sub-indexes of the Global Innovation Index for Ukraine in 2016-2017

including by the index of intangibles it takes $26^{\text {th }}$ place, by creative products and services $-92^{\text {nd }}$, by online creativity $-47^{\text {th }}$ (Figure 1 ).

In addition to the Global Innovation Index, the ranking of countries by the Innovation Efficiency Index is determined, which is calculated on the basis of the same indicators and sub-indices as the Global Innovation Index, by ranking the ratio of the Innovation Output Index to the Innovation Input Index. By this indicator, Ukraine is in $11^{\text {th }}$ place in 2017, which is one position higher than in 2016. This indicates an increase in the efficiency of innovation activity in the country.

\section{Ukraine's rating by the Bloomberg Innovation Index}

The methodology used by Bloomberg in defining the Bloomberg Innovation Index involves analysis of seven factors: R\&D expenditure in relation to GDP; technological opportunities; labour productivity; the number of high-tech enterprises; efficiency of higher education and the percentage of graduates; concentration of researchers; patent activity.

According to the rating provided by Bloomberg in 2018, Ukraine lost 4 positions during the year, which corresponds to the $46^{\text {th }}$ place in the ranking $(47,28$ points) among 50 studied countries. Ukraine proved to be the worst in terms of labour productivity ( $50^{\text {th }}$ place) and fell into the top three outsiders by technological opportunities ( $48^{\text {th }}$ place) (Figure 2).

At the same time, Ukraine retains a high $21^{\text {st }}$ place in the efficiency of higher education, which is calculated based on the share of employees with diplomas of higher education institutions and the number of graduates with engineering and technical higher education. At the same time, it should be noted that compared to the rating in 2017, Ukraine lost 17 positions in terms of higher education. According to patent activity, Ukraine occupies a rather high position $-27^{\text {th }}$ place (Pidbereznyi, 2018).

\section{Assessment of Ukraine's competitiveness by the Global Competitiveness Index}

According to the latest Global Competitiveness Report for 2017-2018 published by the World Economic Forum, Ukraine raised 4 positions above in the ranking and ranked $81^{\text {st }}$ place among 137 studied countries. Bhutan took one position below and ranked $82^{\text {nd }}$ place, while Brazil moved to $80^{\text {th }}$ place. Kazakhstan and Poland have worsened their positions in terms of competitiveness and ranked $57^{\text {th }}$ and $39^{\text {th }}$ place respectively in the general rating this year. Moldova, on the contrary, significantly improved its position and moved from $100^{\text {th }}$ places to $89^{\text {th }}$ place (Schwab, 2017).

The authors of the rating note that Ukraine still holds quite high positions in terms of market capacity ( $47^{\text {th }}$ place), healthcare, basic education $-53^{\text {rd }}$ place. Ukraine has the highest rating in "Higher, secondary, and vocational education" $-35^{\text {th }}$ place, but it is 2 positions worse than in 2016. Ukraine's position deteriorated in 4 out of 12 criteria: infrastructure $-78^{\text {th }}$ place versus $75^{\text {th }}$ place in 2016; labour market efficiency $86^{\text {th }}$ place versus $73^{\text {rd }}$ in 2016 ; innovations $-61^{\text {st }}$ place versus $52^{\text {nd }}$ in 2016; higher, secondary, and vocational education $-35^{\text {th }}$ place versus $33^{\text {rd }}$ in 2016 .

Ukraine's ranking by the innovation sub-index in Report 2017-2018 corresponds to $61^{\text {st }}$ place, i.e. the falling makes 9 positions. Ukraine has worsened its position in the ranking by all indicators of the sub-index.

By the indicator "Innovation", in addition to "Availability of Scientists and Engineers", Ukraine takes $25^{\text {th }}$ place versus $29^{\text {th }}$ in 2016 (Figure 3). 


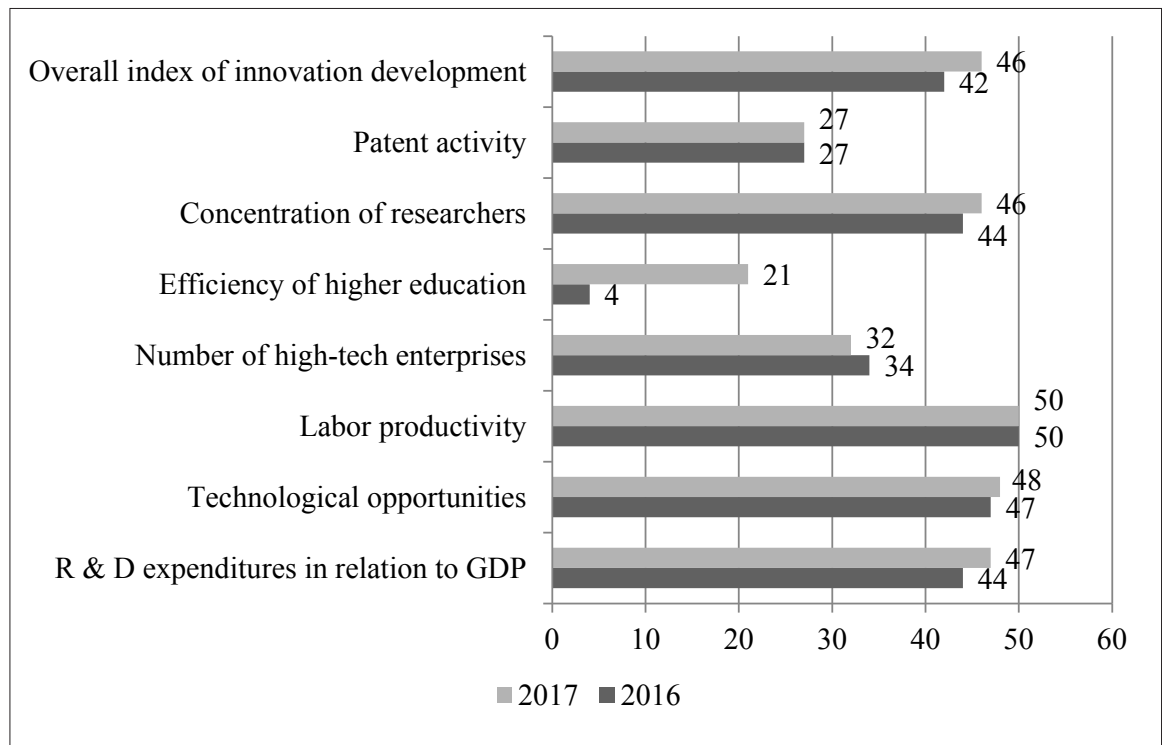

Figure 2. Dynamics of the indicators of the Global Innovation Index for Ukraine in 2016-2017

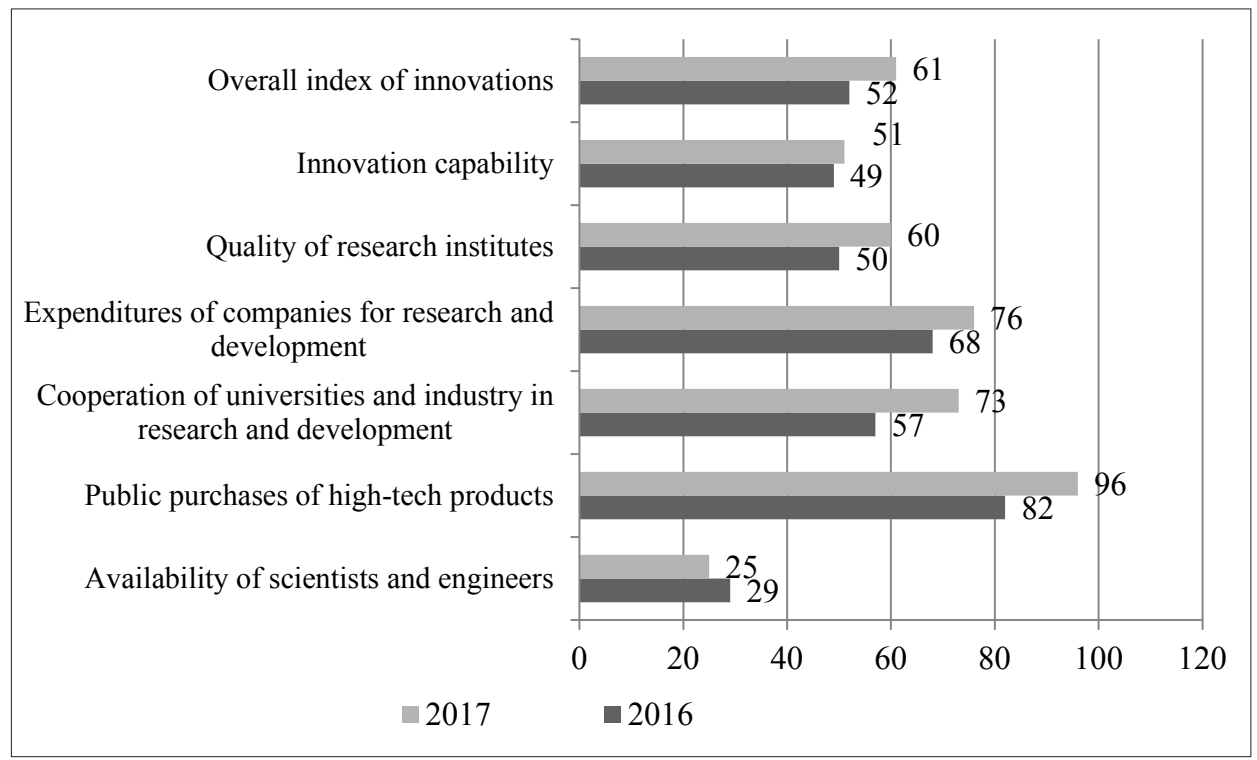

Figure 3. Ukraine's ranking by the indicator "Innovations" of the Global Competitiveness Index in 2016-2017

The largest falling was noted by the criteria as follows: "State purchases of the latest technologies and products" - from 82nd to 96th position of the rating, "Relationship of universities with industry in the field of R\&D” - from 57th to 73rd position.

By the sub-index "Technological readiness", Ukraine ranked 81st place in the ranking versus 85th place in 2016. Ukraine has improved its position in "Use of broadband Internet service/100 persons" - the 63rd place versus 64th in 2016 by one indicator of the sub-index only. By four indicators of the sub-index "Technological readiness", Ukraine has worsened its position in the rating. The most rapid falling is noted by the indicator "Availability of the latest technologies", according to which Ukraine lost 14 positions in the rating. In addition, the most problematic indicator is "Foreign investment and technology transfer" - $118^{\text {th }}$ place (Schwab, 2017).

\section{Ukraine's rating by the European Innovation Scoreboard}

The Innovation Index of the European Innovation Scoreboard reflects the main indicators for assessing the performance of the national innovation system of the EU countries.

All countries included in the Scoreboard are divided into four groups depending on the values of the generalized index: "innovation leaders", "strong innovators", "moderate innovators", and "slow innovators". 
The value of the indicator for Ukraine in 2016 amounted to $28.9 \%$, which indicates a $4.2 \%$ falling compared to 2010. Ukraine belongs to the group of "slow innovators".

Ukraine falls behind in all indicators, except for the indicators of coverage by higher education. Relative strengths of the Ukrainian innovation system are human resources and company investments. The weaknesses are relations and entrepreneurship, the attractiveness of research systems, innovators (Figure 4).

According to the Report in 2017, significant differences of Ukraine are the decline in GDP per capita, lower and negative GDP growth rates, lower and negative population growth rates and lower population density. Among the indicators with positive dynamics, the number of industrial designs, the volume of exports of knowledge-intensive services, and the growth of the number of international joint publications can be distinguished.

\section{Assessment of economy's innovation by the Global Talent Competitiveness Index}

The Global Talent Competitiveness Index is an annual study prepared by INSEAD the Business School for the World in partnership with the Adecco Group and the Institute for Human Capital Leadership Institute (HCLI) in Singapore. This study examines the impact of technological changes on the competitiveness of talents, and it is confirmed that, despite the tendency of displacement of jobs by machines at all levels, technologies also create new opportunities. Basic skills, that are crucial for success, are the ability to work with new technologies and people, flexibility, and collaboration.
The total index is calculated on the basis of the arithmetic mean of six criteria: market and regulatory conditions on the labour market; chances of career growth; employers' ability to attract talents from around the world (Talent Attraction Index); ability to hold qualified staff; industrial skills and global knowledge.

According to the Global Talent Competitiveness Index in 2017, Switzerland and Singapore take leading positions, Great Britain and the United States take the third and fourth place respectively, while the Nordic countries (Sweden, Denmark, Finland, and Norway) rank among top 10 .

Ukraine took $69^{\text {th }}$ place in the overall ranking among 118 studied countries (in $2016-66^{\text {th }}$ place), including by the Talent Attraction Index - an improvement of the position by 3 points (Figure 5) (Badre, 2017).

Ukraine is characterized by good indicators of compulsory education ( $35^{\text {th }}$ place), high-level skills ( $30^{\text {th }}$ place $)$, employment $\left(27^{\text {th }}\right.$ place $)$. But the main problem continues to remain market and regulatory conditions in the labour market $\left(103^{\text {rd }}\right.$ place). This indicator can be raised by improving the regulatory environment $\left(115^{\text {th }}\right.$ place), the business environment and the labour market ( $87^{\text {th }}$ place).

As to the indicators characterizing the technological level of Ukraine, they are included in the criterion "global knowledge", which includes high-level skills and the impact of talent. By the indicator "high-level skills", Ukraine has rather high positions: by the number of researchers $-45^{\text {th }}$ place, the quality of scientific institutes $-41^{\text {st }}$ place, the number of articles in scientific journals $-46^{\text {th }}$ place. And within the framework of the indicator "impact of talent", Ukraine takes $45^{\text {th }}$ place by the indicator "innovation activity" and $86^{\text {th }}-$ by "hightech export”.

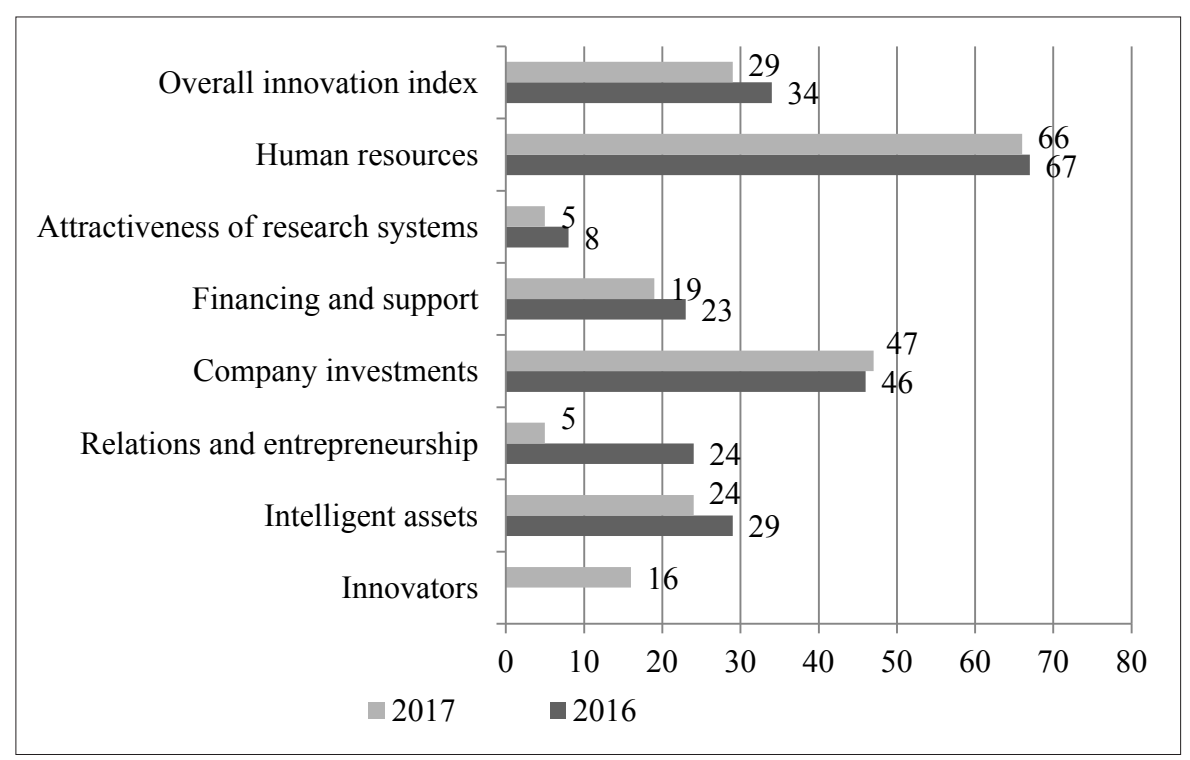

Figure 4. Dynamics of the indicators of the Innovation Index according to the European Innovation Scoreboard for Ukraine in 2016-2017 


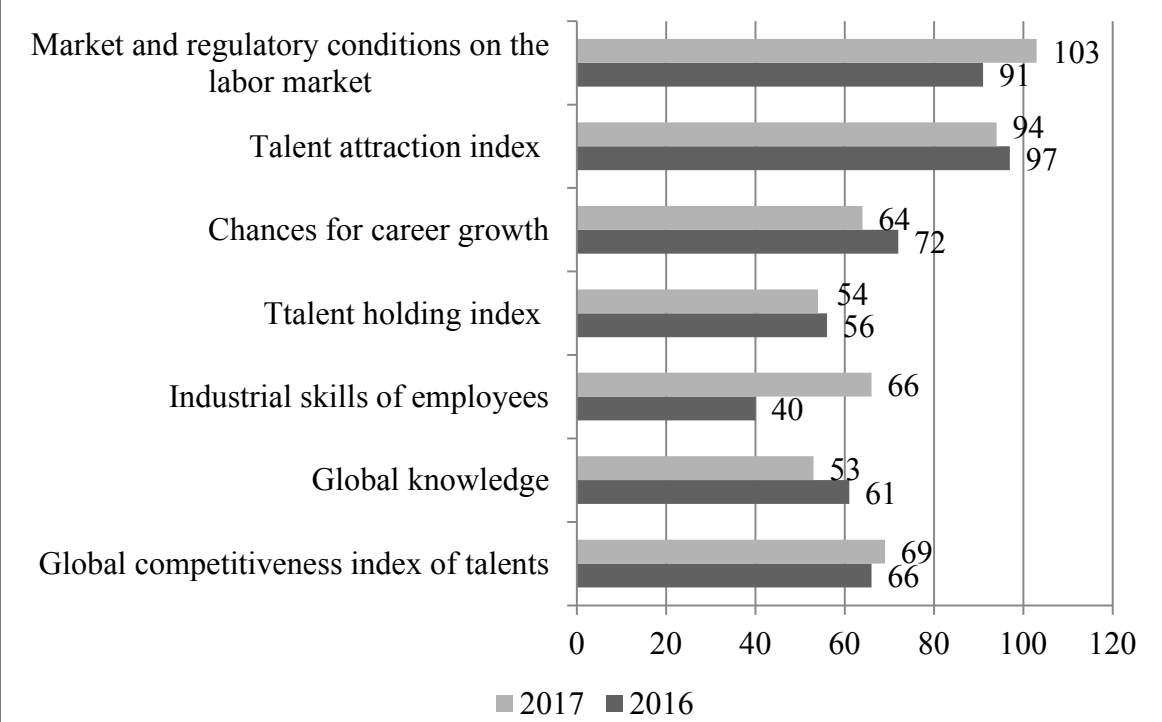

Figure 5. Dynamics of the basic criteria of the Global Talent Competitiveness Index for Ukraine in 2016-2017

Thus, the analysis of the five ratings that assess (or take into account in the process of defining integral assessments) the innovation of the economies of individual countries of the world shows that the formation and implementation of innovative potential and the implementation of innovations in Ukraine are characterized by low indicators. As a rule, such prerequisites for innovation development as human capital, education, and science are assessed relatively high (although there are problematic aspects in these areas over which one must work hard). Stable low assessments (which stipulate the overall rating of the country) have political factors, the state of the regulatory environment and institutional preconditions for the transition to an innovative way of development.

\section{Conclusions}

In order to increase the innovative capacity of the country's economy and within the framework of European integration processes in the field of innovation policy, Ukraine needs to engage in major initiatives, which are implemented in the EU countries by 2020 , namely (2):

- improvement of the framework conditions for innovation activity (accelerating the development of new standards for new products, application of demandoriented policies, etc.);

- implementation of innovative partnerships, for example, related to the development of bioeconomics, developing future-oriented technologies, etc., in order to reduce fragmentation of the efforts between stakeholders at European, national, regional levels and the private sector in overcoming public problems;

- strengthening the means to support innovations (engagement in more active use of structural funds, rural development programs, research framework program, strategic plan for energy technologies, etc.) and simplification of the administrative procedures to facilitate access to financing, especially for small business entities, and implementation of the incentive mechanisms for carbon market-related innovations;

- stimulation of the formation of partnerships and links between education, business, science, and innovations and stimulation of entrepreneurship by supporting young innovative companies.

In Ukraine, these tasks should be transformed into concrete initiatives, in particular:

- acceleration of development and implementation of "innovation laws", in particular, the updated versions of the Laws "On Innovation Activity", "On Technology Transfer", etc., which should provide for simplified procedures for creation of innovative start-ups, distribution of revenues from the sale of innovative products and introduction of a system of public procurement of innovation products. In Ukraine, the volume of public procurement varies quite strongly, when it was about 250 billion UAH in 2014, in 2015 it made only 112 billion UAH. In 2016, the volumes amounted again to over 250 billion UAH. Thus, when establishing $2 \%$ of the level of procurement "innovation" - in addition to the scientific-technical and innovation sphere, it is possible to direct at least 2 to 5 billion UAH. - review of the list and contents of the existing scientific and technical programs for deeper consideration of the world tendencies and their adaptation to the needs of the national economy;

- development of a monitoring system for innovation activity, which would be based on the use of indicators of the European Innovation Scoreboard. The first successful settlement attempt was made in 2016, but the indicators of 
the Scoreboard change periodically requiring appropriate changes in domestic statistics. Furthermore, additional indicators should be introduced for monitoring, in particular, the level of use of ISO standards by domestic companies. Standards open access to external markets, the indicator is a circumstantial evidence of the level of conformity of products manufactured in Ukraine, the needs of international markets.

At present, Ukraine has very limited opportunities to join the funds of the EU structural funds. This applies only to cross-border cooperation. It is necessary to start negotiations with the EU on a wider access to such funds, possibly in the context of expanding the EU's Eastern Partnership activities.

For participation of Ukrainian organizations in joint research programs, there continue to be artificial restrictions on the use of foreign exchange funds, which in fact make it impossible to participate in such projects as a coordinator.
The implementation of financial incentives for the development of innovation should be careful. On the one hand, the Association Agreement encourages the development of free competition without providing special preferences to national companies. On the other hand, according to the dynamics of implementation of such incentives in the countries of the Organization for Economic Cooperation and Development, their range and scope are constantly increasing: if only 17 countries out of 34 had implemented them ten years ago, in 2016 the number of countries was 27 . In the field of research and development (as a part of innovation activity), the opportunities for implementation of the incentives remain significant (there are no contradictions with EU legislation). As to innovative products, it is necessary to introduce pilot projects that will answer the question of how these initiatives will "fit" into the country's legislative system and interact with other legislative and regulatory acts including international ones.

\section{References:}

Badré S. (2017). The Global Talent Competitiveness Index 2017. Retrieved from: http://www.insead.edu/sities/ files/assets/dept/globalindices/GTCI-2017-report.pdf (accessed 23 July 2018)

COM (2010). 2020 final, Europe 2020: A strategy for smart, sustainable and inclusive growth (2010). Official Journal of the European Union (electronic journal). Retrieved from: https://www.eea.europa.eu/policy-documents/ com-2010-2020-europe-2020 (accessed 23 July 2018)

Dutta S., Lanvin B., Wunsch-Vincent S. (2017). The Global Innovation Index 2017. Innovation Feeding the World (electronic journal), vol. 10. 432 p. Retrieved from: http://www.wipo.int/edocs/pubdocs/en/wipo_pub_ gii_2017.pdf (accessed 05 May 2018)

European Innovation Scoreboard 2017 (2017). Internal Market, Industry, Entrepreneurship and SMEs (electronic journal). Retrieved from: http://ec.europa.eu/DocsRoom/documents/24829 (accessed 30 June 2018)

Pidbereznyi K. (2018). Ukraina za rik vtratyla chotyry pozytsii v hlobalnomu innovatsiinomu reitynhu Bloomberg [Ukraine lost four positions in the global innovation rating of Bloomberg Fund Media in a single year]. Fund Media (electronic journal). Retrieved from: https://kfund-media.com/ukrayina-za-rik-vtratyla-chotyry-pozytsiyi-vglobalnomu-innovatsijnomu-rejtyngu-bloomberg/ (accessed 04 July 2018)

Pozytsiia Ukrainy v reitynhu krain svitu za indeksom hlobalnoi konkurentospromozhnosti 2017-2018 (2017). [Position of Ukraine in the world ranking according to the Global Competitiveness Index 2017-2018]. Ekonomichnyi dyskusiinyi klub. Retrieved from: http://edclub.com.ua/analityka/pozyciya-ukrayiny-v-reytyngu-krayin-svitu-zaindeksom-globalnoyi-konkurentospromozhnosti-2 (accessed 10 May 2018)

Schwab K. (2017). The Global Competitiveness Report 2017-2018. 380 p. Retrieved from: http://www3.weforum.org/docs/GCR2017-2018/05FullReport/TheGlobalCompetitivenessReport2017-2018.pdf (accessed 11 July 2018) 